\title{
IPARI RADIOGRÁFIAI MUNKATARTÓVAL KAPCSOLATOS HAZAI KÁRESEMÉNY KATASZTRÓFAVÉDELMI SZEMPONTÚ ANALÍZISE
}

\author{
ANALYSIS OF A DOMESTIC ACCIDENT RELATED TO AN INDUSTRIAL \\ RADIOGRAPHY CAMERA
}

\author{
HORVÁTH Kristóf; KÁTAI-URBÁN Lajos; SEBESTYÉN Zsolt; VASS Gyula \\ (ORCID: 0000-0001-8979-9995); (ORCID: 0000-0002-9035-2450); \\ (ORCID: 0000-0003-3030-856X); (ORCID: 0000-0002-1845-2027); \\ sebestyen@haea.gov.hu; lajos.katai@uni-nke.hu; \\ k.horvath@iaea.org; gyula.vass@katved.gov.hu
}

\begin{abstract}
Absztrakt
Várhatóan a technológia fejlődésével, illetve a Paksi Atomerömü bövitésével párhuzamosan növekedni fog az ipari gamma radiográfiás vizsgálatok, valamint a radiográfiai vizsgáló eszközök száma.

Cikkünk a radiográfiai munkatartóval kapcsolatos balesetekkel foglalkozik, melynek keretében bemutatjuk, hogy milyen eszköz a radiográfiás munkatartó, milyen típusai vannak, valamint a bennük lévő zárt sugárforrások általában milyen izotópok lehetnek.

Ezen felül bemutatjuk, hogy egy esetleges baleset következményeként milyen dózisteljesítmények alakulhatnak ki.

A jelentősebb hazai eseményeket ismertetjük összefoglalóan, míg a Cegléd környékén 2012-ben történt balesetet részletesebben leírjuk, amikor is egy ipari radiográfiai eszközt szállitó cég teherautója egy vasúti átjárón áthaladva vonattal ütközött.
\end{abstract}

Kulcsszavak: sugárvédelem, radiológiai esemény, ipari radiográfia

\begin{abstract}
It can be expected, in parallel the development of technology and the expansion of Paks Nuclear Power Plant that the number of industrial gamma radiography applications and equipment will increase.

Our article deals with accidents related to radiography cameras; it describes the radiographic projectors, their various types, and those typical isotopes that are used as sealed sources within.

In addition, we show what dose rates may develop as a result of a potential accident.

The major domestic events are described in summary, while an accident occurred in Cegléd in 2012, when a truck carrying an industrial radiography device crashed with a train when it was entering a railway crossing, is assessed in more detail.
\end{abstract}

Keywords: radiation protection, radiological event, industrial radiography 


\section{BEVEZETÉS}

Hazánkban egyre nagyobb számban használnak atomenergiát alkalmazó eszközöket különböző célokra. Ezek közül a roncsolásmentes anyagvizsgálatokhoz is használhatnak ionizáló sugárzást, melynek egyik módja a röntgen sugárzást kibocsátó berendezések alkalmazása, mely cikkünknek nem lesz tárgya, másik módja a sugárforrást alkalmazó berendezések. A sugárforrást alkalmazó berendezések egyik típusa az ipari radiográfiás munkatartó, más néven defektoszkóp alkalmazása.

A Paksi Atomerőmü bővítése miatt egyre nagyobb szerepe lesz hazánkban az ipari gamma radiográfiás vizsgáló eszközök használatának, hiszen a létesítési szakaszban az anyagvizsgálatok száma jóval magasabb, mint normál üzemállapotban.

Cikkünkben szeretnénk bemutatni, hogy milyen következményekkel járhat egy sugárforrást alkalmazó eszközzel történő radiológiai esemény. A nukleáris események súlyosságára létrehozott a NAÜ és a Nukleáris Energia Ügynökség együttmüködve egy skálát, melyet radiológiai események osztályozására is továbbfejlesztettek.

Cikkünkben szeretnénk bemutatni egy hazánkban megtörtént balesetet, melyröl eddig még nem történt számadás.

A megértés érdekében összefoglalóan ismertetjük az ipari gamma radiográfia lényegét és fajtáit, valamint megvizsgáljuk a szabadon, árnyékolás nélkül maradt sugárforrás veszélyeit.

\section{RADIOGRÁFIÁS MUNKATARTÓ}

A radiográfiás anyagvizsgálat a roncsolásmentes vizsgálati technikák közé tartozik. Nagy előnye, hogy nem károsítja a vizsgálandó tárgyat, eszközt, berendezést.

Hegesztési varratok, öntvények, müanyagcsövek, betonszerkezetek, durvaszerkezetek megbízhatóan vizsgálhatók gamma-sugárzással. Az ionizáló sugárzás defektoszkópiai célú felhasználását a sugárzás és a vizsgált anyag közötti kölcsönhatások teszik lehetővé. Egy szerkezet üzembiztos müködésének egyik alapvető feltétele, hogy az mentes legyen a szerkezetre veszélyes belső anyaghibáktól. Ismert tény, hogy a gyártási folyamatok mindegyike potenciális hibaforrás is egyben, ezért a fentiekben megfogalmazott feltétel teljesülése csak megfelelően müködő minőségbiztosítási rendszer esetében várható. A radiográfiai vizsgálat tehát egy olyan roncsolásmentes vizsgálati eljárás, mely során anélkül, hogy a vizsgálandó anyagban kárt tennénk, pontosan meg tudjuk állapítani a benne található esetleges hibákat, azok méretét, alakját, elhelyezkedését, típusát.

Hátránya, hogy a vizsgálatokhoz használatos sugárforrás alkalmazása magában hordozhat sokféle veszélyt.

Az izotópos vizsgálat a következőkben tér el a röntgen vizsgálatoktól:

- a hibakimutatás nem olyan jó, mivel az izotóp adott energiájú gamma-részecskét bocsát ki magából, így hullámhosszúsága adott, nem befolyásolható;

- az izotóp aktivitása az idő múlásával csökken, ezért intenzitása egyre kisebb lesz;

- az izotóp a röntgen csővel ellentétben minden irányba sugároz, így egyszerre minden irányba lehet felvételt készíteni, pl. csöveknél körvarratra alkalmas;

- az izotópok gamma-sugárzásának energiája nagyobb, mint az anyagvizsgálatokhoz használt röntgen sugárzás energiája, így vastagabb anyagot is képes átvilágítani, ugyanakkor az intenzitásuk kisebb, mint a röntgen sugárzásé, így az expozíciós idő hosszabb lehet.

Az izotópos anyagvizsgálat egyik módszere, hogy úgynevezett radiográfiás munkatartóba zárják a sugárforrást, amit az anyagvizsgálatokhoz használnak. 


\section{Alkalmazott izotópok}

A radiográfiai anyagvizsgálatokhoz többféle izotópot használhatnak, melyek mindegyike gamma-sugárzó izotóp. A radiográfia az anyagon áthaladó ionizáló sugárzást hasznosítja az anyagban lévő folytonossági hiányok kimutatására. A sugárforrásból érkező fotonok a vizsgálati darabon áthaladva, a filmen sötétedést okoznak. Minél több foton halad át, annál sötétebb foltot kaphatunk. A vizsgálandó darabon a hibák elvékonyodást, repedéseket jelenthetnek, melyek több fotont engednek át, mint a darab azon része, mely ép. Az itt leírtak szemléltetésére szolgál a 1 . ábra.

\section{Sugárforrás}

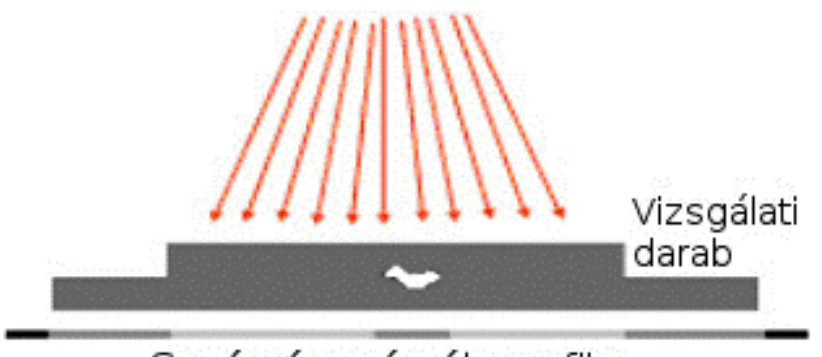

Sugárzásra érzékeny film

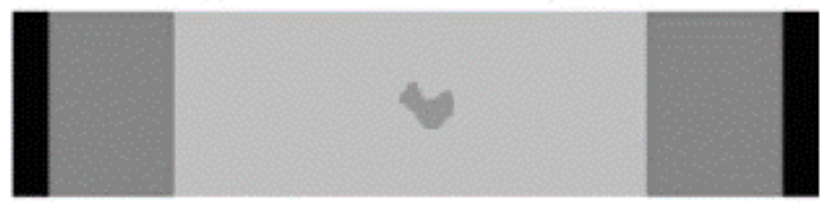

Az elöhívott film felülnézete

=Kevesebb sugárzás

=Több sugárzás

1. ábra A radiográfiás anyagvizsgálat elvének sematikus ábrája [1]

A sugárforrással történő radiográfiás anyagvizsgálat során 5 izotópot alkalmaznak a legyakrabban, melyeknek jellemző adatait a 1. táblázat tartalmazza, ahol megtalálhatjuk az izotóp rendszámát, felezési idejét, valamint a jellemző gamma vonalainak energiáját és gyakoriságát. 


\begin{tabular}{|c|c|c|c|c|}
\hline Radionuklid & Rendszám & $\mathbf{T}_{\mathbf{1} / \mathbf{2}}$ & $\mathbf{E}_{\gamma}(\mathbf{k e V})$ & k (\%) \\
\hline \multirow{2}{*}{ Co-60 } & \multirow{2}{*}{27} & \multirow{2}{*}{5,27 év } & 1173 & 100 \\
\hline & & & 1333 & 100 \\
\hline \multirow{5}{*}{ Se-75 } & \multirow{5}{*}{34} & \multirow{5}{*}{$\begin{array}{c}119,8 \\
\text { nap }\end{array}$} & 121 & 17 \\
\hline & & & 136 & 59 \\
\hline & & & 265 & 59,2 \\
\hline & & & 279,5 & 25,2 \\
\hline & & & 401 & 11 \\
\hline Cs-137 & 55 & 30,2 év & 662 & 85 \\
\hline \multirow{6}{*}{ Yb-169 } & \multirow{6}{*}{70} & \multirow{6}{*}{32 nap } & 63 & 43,6 \\
\hline & & & 109,8 & 17,4 \\
\hline & & & 130,5 & 11,4 \\
\hline & & & 177,2 & 22,3 \\
\hline & & & 198 & 35,9 \\
\hline & & & 307,7 & 10 \\
\hline \multirow{5}{*}{ Ir-192 } & \multirow{5}{*}{77} & \multirow{5}{*}{73,8 nap } & 296 & 28,7 \\
\hline & & & 308,4 & 29,7 \\
\hline & & & 317 & 83 \\
\hline & & & 468 & 48 \\
\hline & & & 604 & 8 \\
\hline
\end{tabular}

1. táblázat Radiográfiás anyagvizsgálatok jellemző izotópjai és tulajdonságai [2]

\section{Radiográfiás munkatartók}

A nagy aktivitás miatt igen nehéz leárnyékolni a sugárforrásokat úgy, hogy valamennyire mobilis is maradjon. A sugárforrásokat ezért munkatartókba helyezik, melyek általában szegényített uránból készült árnyékolással rendelkeznek, mivel a gamma-sugárzás hatékony árnyékolásához nagy tömegszámú elemekre van szükség. A következő képen (2. ábra) egy radiográfiás munkatartó sematikus rajza látható.

\section{Sugárforrás Titánium 'S' cső Árnyékolt tároló}

Dugattyúzár

Záró mechanizmus

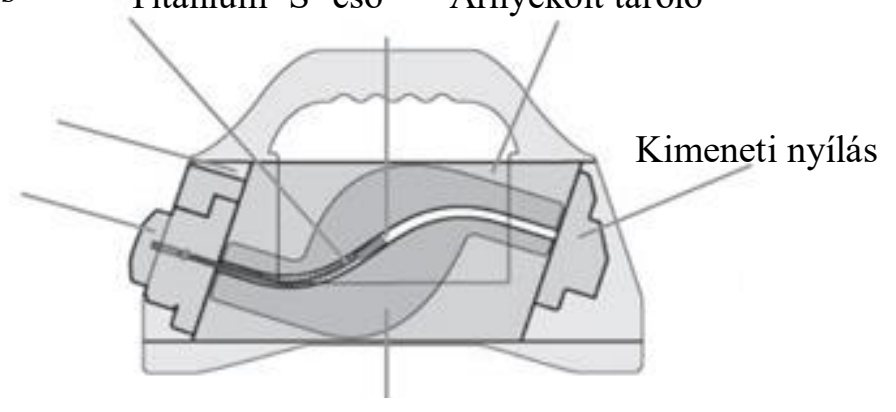

Szegényített urán árnyékolás

2. ábra egy radiográfiás munkatartó sematikus rajza és főbb részei [3]

Annak érdekében, hogy ne okozzon többlet sugárterhelést a kezelő számára, távirányítással engedik ki a forrást, illetve húzzák vissza. A munkatartóhoz egy flexibilis csövet csatlakoztatnak, amiben a sugárforrás tud mozogni. A sugárforrás maga egy kapszulában helyezkedik el (3. ábra), hogy a flexibilis csöben könnyen, akadásmentesen tudjon mozogni. 


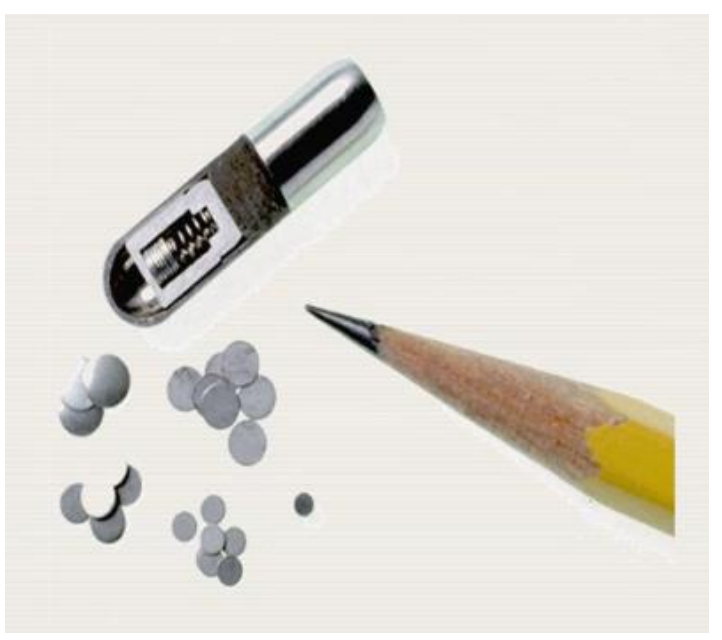

3. ábra A radiográfiás vizsgálatokhoz használatos sugárforrások leggyakrabban használt formája [4]

A sugárforrás alaphelyzetben a tartójában van. Az expozícióhoz kiengedik a sugárforrást úgy, hogy közben a kezelő árnyékolt helyzetben legyen, majd a megfelelő expozíciós idő elteltével a sugárforrást vissza lehet engedni eredeti helyére. Amennyiben valamilyen oknál fogva nem tudna visszakerülni az árnyékolt állapotába, fontos, hogy a kezelö azonnal tudomást szerezzen róla. Mivel igen nagy aktivitású sugárforrásokat alkalmaznak, ezért igen rövid idő alatt is akár determinisztikus hatással járó sugárterhelést okozhat a kezelönek. A könnyebb megértést a 4. ábra segíti.

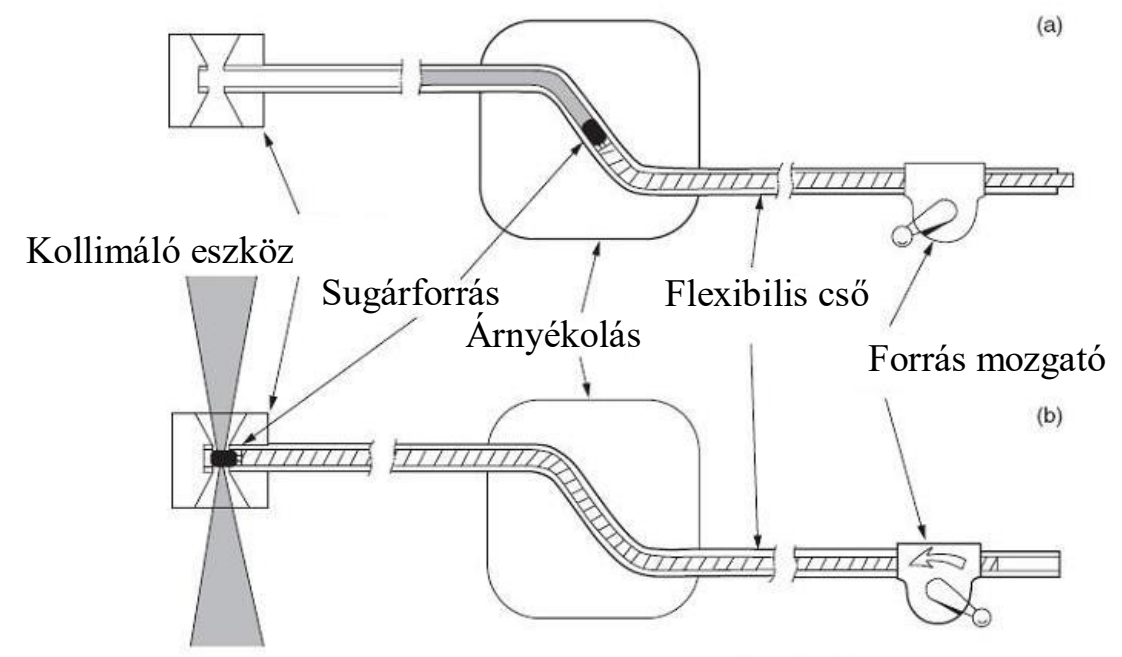

4. ábra A sugárforrás mozgatásának sematikus képe, a sugárforrás a) árnyékolt állapotban, b) expozíciós állapotban [3]

A fent alkalmazott módszerek, védelmek segítségével a 2 . táblázat szerinti maximális aktivitást lehet alkalmazni. 


\begin{tabular}{|c|c|c|}
\hline Izotóp & Felezési idő & Aktivitás \\
\hline Ir-192 & 74 nap & $5,55 \mathrm{TBq}$ \\
\hline $\mathrm{Se}-75$ & 119,8 nap & $7,4 \mathrm{TBq}$ \\
\hline $\mathrm{Co}-60$ & 5,27 év & $2,4 \mathrm{GBq}$ \\
\hline $\mathrm{Cs}-137$ & 30,17 év & $14 \mathrm{GBq}$ \\
\hline Yb-169 & 32 nap & $1,11 \mathrm{TBq}$ \\
\hline
\end{tabular}

2. táblázat Radiográfiás vizsgálatokhoz leggyakrabban alkalmazott sugárforrások fajtái, illetve maximális aktivitásuk [5]

A radiográfiás munkatartókkal több cég is foglalkozik, igen sokféle elérhető a piacon, de az elve mindnek ugyanaz. A továbbiakban szeretnénk bemutatni a cikkünkkel érintett radiográfiás munkatartót részletesebben.

\section{Gammamat $^{\mathrm{TM}}$ TSI 3/1 [6]}

A tradicionális német gyártó Gammamat ${ }^{\mathrm{TM}}$ TI, TI-F és TI-FF típusú tartóiból továbbfejlesztett, legújabb TSI 3/1 és TSI 5/1 munkatartója ipari körülmények között is kiválóan és biztonságosan használható.

A munkatartók geometriai kialakítása során sikerült megoldani, hogy jól felhelyezhetők legyenek csővezetékekre is, illetve külső behatásoktól, ütésektől megvédjék a csatlakozó egységeket. Megfelelnek az érvényes európai szállítási feltételeknek, urán árnyékolással rendelkeznek, biztonsági reteszeléssel vannak ellátva, korszerü, megbízható készülékek.

A maximális biztonság elérése érdekében, amennyiben a kivezető cső nincs csatlakoztatva a készülékhez, vagy a biztonsági reteszelés nincs kiiktatva, a felvételkészítés nem lehetséges.

$\mathrm{Az}$ újonnan kifejlesztett, II. generációs kivezérlő szerkezet segítségével a nehezen vizsgálható helyekre is könnyebben és pontosabban juttathatjuk el az izotópot.

A TSI 3/1 izotóptartó tulajdonságai:

- A készülék felszínén mért dózisteljesítmény: $2 \mathrm{mSv} / \mathrm{h}$

- Betölthetö izotóp: Ir-192

- Betölthető aktivitás: 3,0 TBq ( 80 Ci)

- Kivezérlő szerkezet hossza: 10 fm (standard)

- Kivezető cső hossza: 3 fm (standard)

- A készülék súlya: $20 \mathrm{~kg}$

- A készülék méretei (HxSzxM): 350x132x222 mm

- Az Urán árnyékolás súlya: $10,9 \mathrm{~kg}$

- A készülék anyaga: CrNi acél és Alumínium

- Tartó besorolása: CDN/2086/B(U)-96

Felhasználási területük:

- Csővezetékek, nyomástartó edények

- Repülőgépipar, olaj és gázipar

- Hídépítés, atomerőmüvek

\section{POTENCIÁLIS VESZÉLYEK A FORRÁS KIKERÜLÉSÉVEL}

Egy radiográfiás munkatartó úgy van megtervezve, hogy ne kerüljön ki nem kívánt módon a radioaktív sugárforrás. Ennek érdekében a konténert különböző teszteknek vetik alá, úgymint:

- Ejtés $1 \mathrm{~m}$-röl rúdra $(\mathrm{d}=15 \mathrm{~cm}$, magasság: $\min .20 \mathrm{~cm})$ 
- Ejtés 9 m-röl ütközőlapra, vagy (amennyiben a küldeménydarab tömege kisebb, mint $500 \mathrm{~kg}$, és az átlagos sürüsége kisebb mint $1 \mathrm{t} / \mathrm{m}^{3}$, nem különleges formájú radioaktív tartalom, nem több $1000 \mathrm{~A}_{2}$-nél )

- $1 \mathrm{~m} \mathrm{x} 1 \mathrm{~m}$-es, $500 \mathrm{~kg}$ tömegü acél lap ráejtés 9 m magasból

- Hőpróba: 30 percig legalább $800{ }^{\circ} \mathrm{C}$-os lángba.

A próbák lényege, hogy ezen eseményeket következően is elegendő árnyékoló hatása maradjon, amely biztosítja, hogy a sugárzási szint a küldeménydarab felületétöl $1 \mathrm{~m}$ távolságban nem haladja meg a $10 \mathrm{mSv} / \mathrm{h}$ értéket a legnagyobb radioaktív tartalom esetén, amelynek befogadására a küldeménydarabot tervezték.

A tesztek ellenére előfordulhatnak olyan események, amikor a sugárforrás nem marad a munkatartóban, esetleg a kapszula is megsérül. Ilyen esetekben külső és belső sugárterhelésekröl beszélhetünk.

Az elsőként a helyszínre érkezők vannak a legnehezebb helyzetben, hiszen még nem lehet tudni, hogy egy esetleges baleset során történt-e ilyen jellegü sérülés. A következökben szeretném bemutatni, hogy miként lehet egyszerü számítási módszerrel meghatározni, hogy mekkora sugárterhelés érheti a kiérkező egységeket (tüzoltók, katonák, rendőrök) a megfelelő ellenőrzések elvégzése nélkül.

\section{Külső sugárterhelés}

A sugárforrás kikerülésével olyan dózisteljesítményü helyek alakulhatnak ki, melyekben tartózkodva akár a determinisztikus dózis küszöbértékét $(500 \mathrm{mSv})$ is elérhetjük. A determinisztikus hatás valamilyen biztos károsodást jelent a szervezetre. A küszöbérték felett a dózis növekedésével nem a kialakulás valószínüsége növekszik, mint a sztochasztikus hatásoknál, hanem a kialakult degradáció súlyossága.

A sugárforrások körül lévő dózisteljesítmény megállapításához egy egyszerü képletet lehet alkalmazni, amiből a különböző távolságokra lévő személy effektív dózisát ki lehet számítani az ott töltött idő ismeretében. [7]

D: dózisteljesítmény $(\mathrm{mSv} / \mathrm{h})$

$$
\dot{D}=c \cdot A \cdot \frac{r_{0}{ }^{2}}{r^{2}}
$$

c: külső sugárterheléshez használatos súlyozó tényező, mekkora dózisteljesítményt eredményez $30 \mathrm{~cm}$-re az adott izotóp $1 \mathrm{MBq}$-ére vonatkoztatva, a sugárforrást pontforrásnak tekintjük (mSv/h /MBq)

A: adott izotóp aktivitása (MBq)

$\mathrm{r}_{0}^{2}: 0,3 \mathrm{~m}$

$\mathrm{r}^{2}$ : a sugárforrástól mért távolság $(\mathrm{m})$

A kézikönyvben lévő adatok alapján a 3 leggyakrabban alkalmazott izotópra elvégeztük a számítást 30 és $50 \mathrm{~cm}$-re, valamint 1 és $10 \mathrm{~m}$-re.

\begin{tabular}{|c|c|c|c|c|c|c|}
\hline Izotóp & A & c & $\dot{\mathbf{D}}(\mathbf{m S v} / \mathbf{h})$ & $\dot{\mathbf{D}}(\mathbf{m S v} / \mathbf{h})$ & $\dot{\mathbf{D}}(\mathbf{m S v} / \mathbf{h})$ & $\dot{\mathbf{D}}(\mathbf{m S v} / \mathbf{h})$ \\
\hline & $\mathbf{M B q}$ & $\mathrm{mSv} / \mathrm{h} / \mathbf{M B q}$ & & & & \\
\hline \multicolumn{7}{|c|}{ A dóziskonverziós tényező 30 cm-re vonatkoztatva [7] } \\
\hline & 2400 & $3,86 \mathrm{E}-03$ & $9,26 \mathrm{E}+00$ & $3,34 \mathrm{E}+00$ & & \\
\hline & 14000 & & & & & \\
\hline & 5550000 & 1,54E-03 & $8,55 \mathrm{E}+03$ & $3,08 \mathrm{E}+03$ & $7,69 \mathrm{E}+02$ & 7,69 \\
\hline \multicolumn{7}{|c|}{ A dóziskonverziós tényező 100 cm-re vonatkoztatva [8] } \\
\hline $\mathrm{Se}-75$ & 7400000 & $2,32 \mathrm{E}-04$ & $1,91 \mathrm{E}+04$ & $6,88 \mathrm{E}+03$ & $1,72 \mathrm{E}+03$ & $1,72 \mathrm{E}+01$ \\
\hline
\end{tabular}




\begin{tabular}{|c|c|r|c|c|c|c|}
\hline Izotóp & $\mathbf{A}$ & \multicolumn{1}{c|}{$\mathbf{c}$} & $\dot{\mathbf{D}}(\mathbf{m S v} / \mathbf{h})$ & $\dot{\mathbf{D}}(\mathbf{m S v} / \mathbf{h})$ & $\dot{\mathbf{D}}(\mathbf{m S v} / \mathbf{h})$ & $\dot{\mathbf{D}}(\mathbf{m S v} / \mathbf{h})$ \\
\hline & $\mathbf{M B q}$ & $\mathbf{m S v} / \mathbf{h} / \mathbf{M B q}$ & $\mathbf{3 0} \mathbf{~ c m}-\mathbf{r e}$ & $\mathbf{5 0} \mathbf{c m}-\mathbf{r e}$ & $\mathbf{1} \mathbf{m}-\mathbf{r e}$ & $\mathbf{1 0} \mathbf{~ m - r e}$ \\
\hline $\mathrm{Yb}-169$ & 1110000 & $8,84 \mathrm{E}-05$ & $1,09 \mathrm{E}+03$ & $3,92 \mathrm{E}+02$ & $9,81 \mathrm{E}+01$ & $9,81 \mathrm{E}-01$ \\
\hline
\end{tabular}

3. táblázat $\mathrm{A}$ jellemző dózisteljesítmények a különböző sugárforrások közelében 30 és $50 \mathrm{~cm}$-re, illetve 1 és 10 m-re a sugárforrástól [7] [8]

Ugyanakkor az interneten elérhető egy online program, aminek a segítségével könnyedén elvégezhető ez a számítás az aktivitás, illetve a távolság megadásával. A program segítségével elvégeztük a jellemző izotópok dózisteljesítményére a számítást és a 4. táblázat szerinti értékeket kaptuk, amennyiben a forrás szabadon, árnyékolás nélkül van. [9]

\begin{tabular}{|c|c|c|c|c|c|}
\hline Izotóp & Aktivitás & $\begin{array}{c}\dot{\mathrm{D}}(\mathrm{mSv} / \mathrm{h}) \\
10 \mathrm{~cm}-\mathrm{re}\end{array}$ & $\begin{array}{c}\dot{\mathrm{D}}(\mathrm{mSv} / \mathrm{h}) \\
50 \mathrm{~cm}-\mathrm{re}\end{array}$ & $\begin{array}{c}\dot{\mathbf{D}}(\mathrm{mSv} / \mathrm{h}) \\
1 \mathrm{~m}-\mathrm{re}\end{array}$ & $\begin{array}{c}\dot{\mathrm{D}}(\mathrm{mSv} / \mathrm{h}) \\
10 \mathrm{~m}-\mathrm{re}\end{array}$ \\
\hline Ir-192 & $5,55 \mathrm{TBq}$ & 60600 & 2514 & 606 & 6,06 \\
\hline Se-75 & $7,4 \mathrm{TBq}$ & 34000 & 1357 & 340 & 3,4 \\
\hline Co-60 & $2,4 \mathrm{GBq}$ & 73,7 & 2,95 & 0,74 & 0,0074 \\
\hline Cs-137 & $14 \mathrm{GBq}$ & 106 & 4,27 & 1,06 & 0,0106 \\
\hline Yb-169 & $1,11 \mathrm{TBq}$ & 2886 & 115 & 28,86 & 0,2886 \\
\hline
\end{tabular}

4. táblázat $\mathrm{A}$ jellemző dózisteljesítmények a különböző sugárforrások közelében 10, $50 \mathrm{~cm}$-re, illetve 1 és 10 m-re a sugárforrástól [9]

A táblázat jól mutatja, hogy az alkalmazott sugárforrások közvetlen környezetében akár rövid ideig történő tartózkodással is könnyedén emelkedhet a sugárterhelés mértéke a determinisztikus hatások küszöbértéke fölé.

\section{KORÁBBI ESEMÉNYEK}

Hazánkban több esetben előfordult ipari gamma radiográfiával kapcsolatos esemény, melyeket Ballay László és társai bemutattak cikkükben: [10]

\begin{tabular}{|l|l|l|l|l|}
\hline Év & Izotóp & Aktivitás & $\begin{array}{l}\text { INES } \\
\text { szint }\end{array}$ & \multicolumn{1}{|c|}{ Következmények } \\
\hline 1976 & Ir-192 & & 1 & $\begin{array}{l}\text { Lengyel gyártmányú radiográfiai } \\
\text { sugárforrás(ok) nyitottá válása. Eszközök } \\
\text { elszennyeződtek. }\end{array}$ \\
\hline 1977 & Ir-192 & & 3 & $\begin{array}{l}1,2 \text { Gy egésztest } \\
\text { A radiográfus a besugárzást árnyékolatlan } \\
\text { radiográfiai sugárforrás hosszú közúti } \\
\text { szállítása közben szenvedte el. }\end{array}$ \\
\hline 1984 & Ir-192 & $1,11 \mathrm{TBq}$ & 3 & $\begin{array}{l}\text { 20-30 Gy, ujjsérülés } \\
\text { A sugárforrást befogó eszköz, az ún. ,torpedó” } \\
\text { elgörbült rugós részét próbálta javítani a } \\
\text { munkavállaló. }\end{array}$ \\
\hline 1988 & Cs-137 & & 1 & $\begin{array}{l}\text { Több évtizede gyártott radiográfiai forrás(ok) } \\
\text { vált(ak) nyitottá ( 10 GBq). Üzemi területen } \\
\text { belül maradó szennyezés. }\end{array}$ \\
\hline 1991 & Ir-192 & $1,1 \mathrm{TBq}$ & 0 & Lakótelepen leoldódott forrás. \\
\hline
\end{tabular}




\begin{tabular}{|l|l|l|l|l|}
\hline Év & Izotóp & Aktivitás & $\begin{array}{l}\text { INES } \\
\text { szint }\end{array}$ & \multicolumn{1}{|c|}{ Következmények } \\
\hline 1999 & Ir-192 & $300 \mathrm{GBq}$ & 2 & $\begin{array}{l}\text { 2 radiográfus, 350 és 200 mSv } \\
\text { A sugárforrást tartalmazó ,torpedó” a kivezető } \\
\text { gégecsőben maradt. }\end{array}$ \\
\hline 1999 & Ir-192 & $70 \mathrm{GBq}$ & 1 & $\begin{array}{l}3 \text { takarító, max. 6 mSv/fó, 2 munkás, max. 2,5 } \\
\text { mSv/fó } \\
\text { Torpedó leoldódott, amit nem vettek észre. } \\
\text { Takaritók szemetesbe helyezték. }\end{array}$ \\
\hline 2001 & Ir-192 & $800 \mathrm{GBq}$ & 0 & Üzemcsarnokban leoldódott forrás. \\
\hline 2009 & Ir-192 & $1 \mathrm{TBq}$ & 0 & $\begin{array}{l}\text { Radiográfiai sugárforrás vált nyitottá. } \\
\text { Időben felfedezték. }\end{array}$ \\
\hline
\end{tabular}

5. táblázat Hazai ipari radiográfiás sugárforrással bekövetkező események. [10]

A leírtakból, valamint a táblázatból is látható, hogy milyen veszélyeket hordozhat magában a sugárforrás árnyékolatlan állapotba kerülése. Pl. a legegyszerübbnek gondolt hiba javítása is komoly sugárterhelést jelenthet az ujjnak, ami annak elvesztését is eredményezheti, vagy az árnyékolatlan állapotban maradt sugárforrás könnyen a dóziskorlát feletti sugárterhelést okozhat. Ez utóbbi könnyen ellenőrizhető, ha a radiográfus az elöírásnak megfelelően rendelkezik kézi dózisteljesítménymérő müszerrel, illetve használja is azt.

Az ipari gamma radiográfiás, radiológiai eseményeknél a Katasztrófavédelemnek nagy segítségére lehetnek az elveszett sugárforrás felderítésére alkalmazandó légi felderítő egységek. Zelenák János és társai cikkükben bemutatják, hogy milyen lehetőségei lehetnek az elveszett sugárforrás légi felderítésének. Cikkükben megadják, hogy mely izotópok detektálhatóak légi felderítéssel. Mivel az ipari gamma radiográfiához jellemzően használt izotópok gamma sugárzó radioaktív izotópok, így a cikkben felsorolt izotópok között megtalálhatóak. [11]

A sugárfelderítő helikopter egy úgynevezett vegyi-sugárfelderítő konténerrel van felszerelve, amiben több detektor is található. Ezek a következők:

- BNS-98 típusú dózisteljesítmény-távadó (GM csöves nukleáris detektor);

- NDI/SK típusú intelligens szcintillációs nukleáris detektor, speciális üreges $\mathrm{NaI}(\mathrm{Tl})$ kristállyal, ólom kollimátorban, beépített sugárkapu algoritmussal;

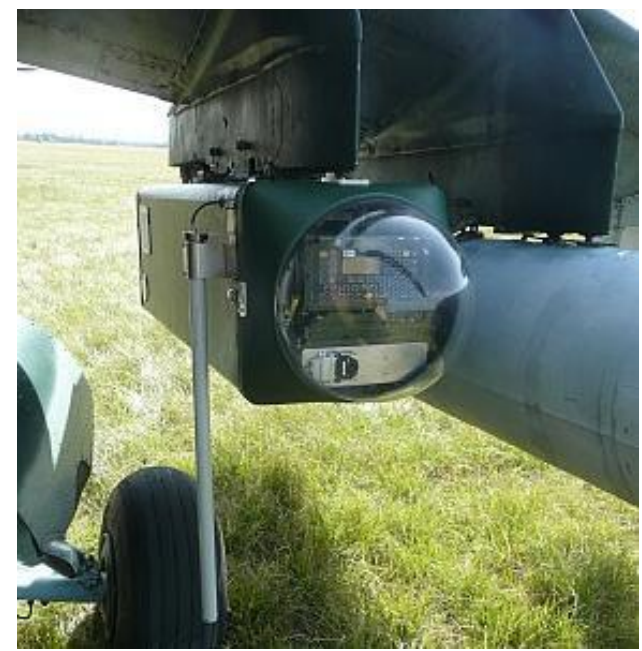

5. ábra MI-24-re függesztett ABV RIÉR konténer [12]

Az egyes detektor típusok müködési elvét, illetve tulajdonságait mutatják be Solymosi József és társai cikkükben. [13] 


\section{VONAT BALESET EGY RADIOGRÁFIÁS MUNKATARTÓVAL}

2012. december 11-én egy radiográfiás munkatartót szállító kis teherautó vélhetően piros jelzésen haladt át egy vasúti átjárón Cegléd és Nyársapát között, amikor is egy Intercity szerelvénnyel ütközött. A balesetben a vonat utasai közül senki sem sérült meg, a kisteherautó utasai azonban súlyos sérüléseket szenvedtek, őket kórházba szállították. A vonat utasaiért mentesítő járatot küldtek. [14]

A Pest Megyei Katasztrófavédelmi Igazgatóság műveletirányítási központját értesítették, amely a helyszínre irányította a megyei Katasztrófavédelmi Mobil Labor egységet és a BM Országos Katasztrófavédelmi Főigazgatóságnál szolgálatot teljesítő Katasztrófavédelmi Sugárfelderítő Egységet. Mindkét szolgálat a jármüveken rendelkezésre álló sugárfelderítő eszközökkel (IH-295, BNS-94 FM sugárkapu, Identifinder, PRM-470CG) méréseket végeztek, így meghatározták a biztonsági zónát, amelyen belül csak az arra illetékes és személyi dózis mérővel ellátott szakemberek tartózkodhattak.

A teherautó szállítási okmányai szerint Ir-192 volt a munkatartóban, mégpedig 1,1 TBq.

Az ütközésben a teherautó is súlyos károsodást szenvedett, a szállításra szolgáló hátsó rakodó tér leszakadt a jármüröl (6. ábra).

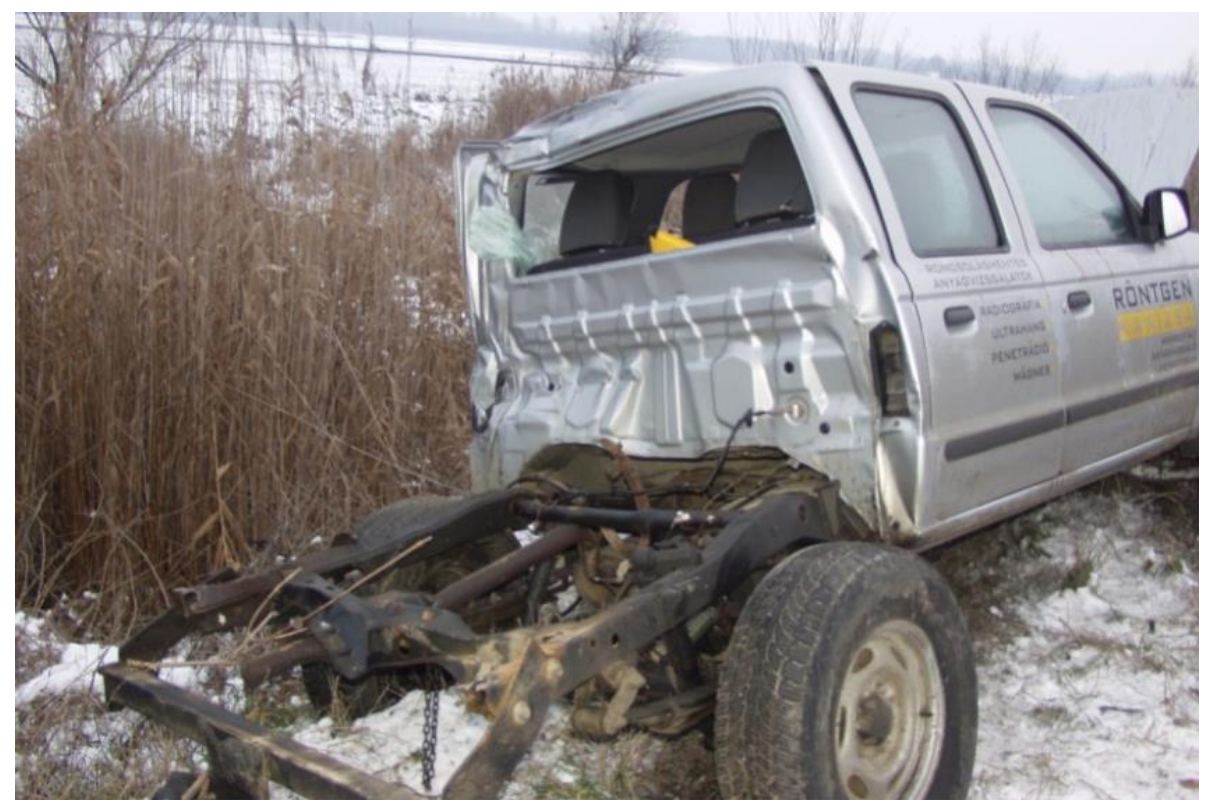

6. ábra A balesetben sérült teherautó [15]

Az ütközés következtében a munkatartó szállitására szolgáló doboz lerepült a teherautó platójáról, így az ütközést követően nem volt ismert a sugárforrás kiléte. A Katasztrófavédelem egységei találták meg a dobozt a vonat pálya melletti magas gazban, több $10 \mathrm{~m}$-re a helyszíntől. A csomagolás a sugárforrás veszélyességére való tekintettel $B(U)$ minősítésü, mely méretezve van ilyen helyzetekre is. A 7. ábra mutatja a munkatartó tároló dobozának állapotát az ütközést követően. 


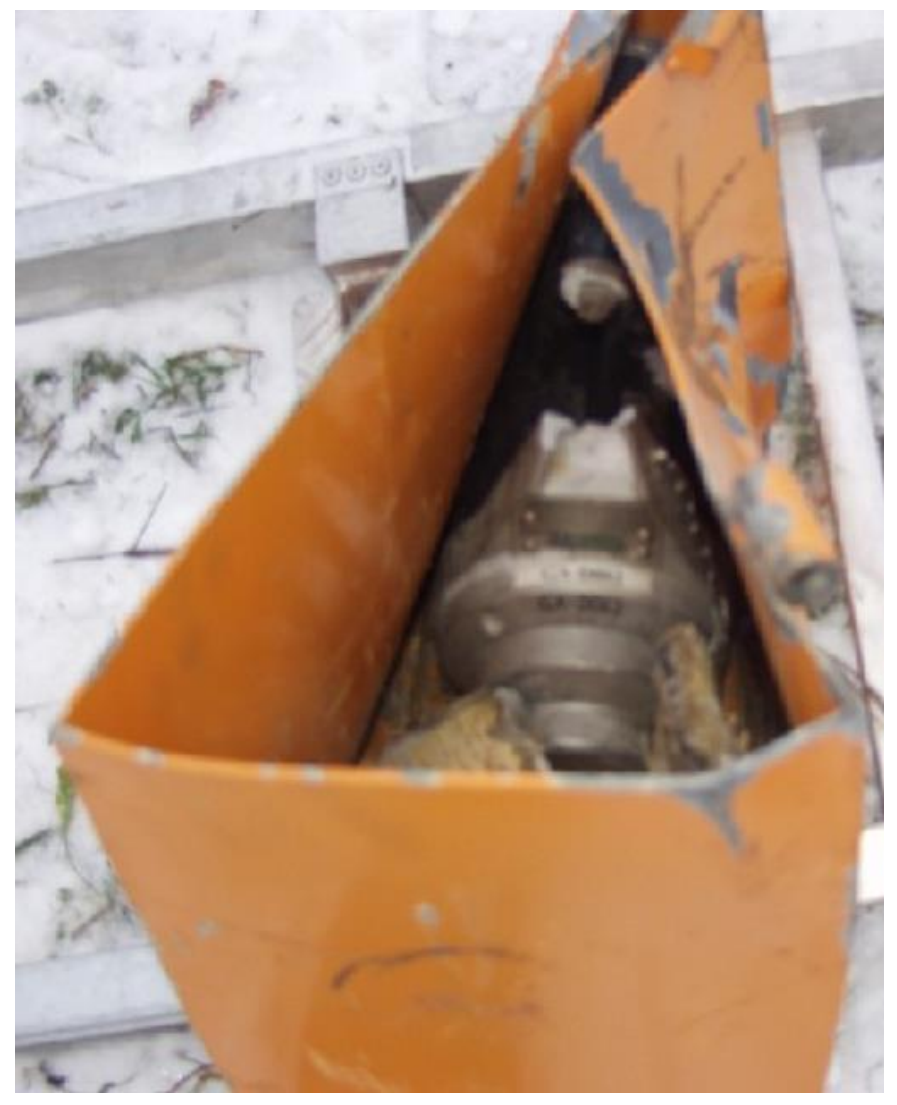

7. ábra A balesetben sérült Gammamat munkatartó ládája [15]

A munkatartót elszállították és vizsgálatot követően eltávolították a sugárforrást. A sugárforrás nem sérült, a csomagolás megfelelőségének köszönhetően.

A 4. táblázat alapján, ha az aktivitások arányával beszorozzuk, akkor is $10 \mathrm{~m}$-re kb. $1,2 \mathrm{mSv} / \mathrm{h}$ dózisteljesítmény lett volna mérhető, ha a sugárforrás kiszabadul. Ez alapján könnyen eldönthető volt, hogy a sugárforrás kijutott-e a környezetbe. Ha kijutott volna, az dózisteljesítmény mérő müszerrel mindenképpen mérhető lett volna.

Miután megtalálták a tároló dobozt, a Katasztrófavédelem egységei kiszállították a gazból. Az ellenőrző mérés a munkatartó felületén maximálisan $60 \mu \mathrm{Sv} / \mathrm{h}$ dózisteljesítmény értéket adott. Mivel a munkatartó szegényített uránt tartalmaz, ezért sugárforrás nélkül is mérhető sugárzás körülötte, normális esetben $2-3 \mu \mathrm{Sv} / \mathrm{h}$. A sérült munkatartó körül mérhető maximális dózisteljesítményböl arra lehetett következtetni, hogy a sugárforrás árnyékolt helyzetben maradt, mivel a munkatartó felületén üres helyzetben nem mérhető akkora sugárzás, illetve az árnyékolás hiánya következtében jóval nagyobb dózisteljesítmény lett volna mérhető.

A sugárforrás szállításához a katasztrófavédelem a helyszínre rendelte az Országos Sugárbiológiai és Sugáregészségügyi Kutató Intézet készenléti egységét, akik a rendelkezésükre álló speciális jármüvel nem tudták elszállítani a sérült munkatartót, mivel az Ir-192 aktivitása a tárolóba helyezhető maximális aktivitás értéknél magasabb volt. Az elszállításhoz a KBFI-UNIÓ Kft. szállító jármüvét vették igénybe, akik a telephelyükre szállították a sérült munkatartót a sugárforrással együtt.

A sérült munkatartó, illetve a benne lévő sugárforrás állapota nem volt ismert, ezért azt különös elővigyázatosággal kellett megvizsgálni, felkészülve arra, hogy a kapszula is sérülhetett az ütközés során. A KBFI-UNIÓ Kft. úgynevezett forró fülkében hajtotta végre a vizsgálatot és azt tapasztalta, hogy ugyan a defektoszkópon sérülések voltak láthatóak (8. ábra), ugyanakkor a sugárforrás nem sérült meg. 


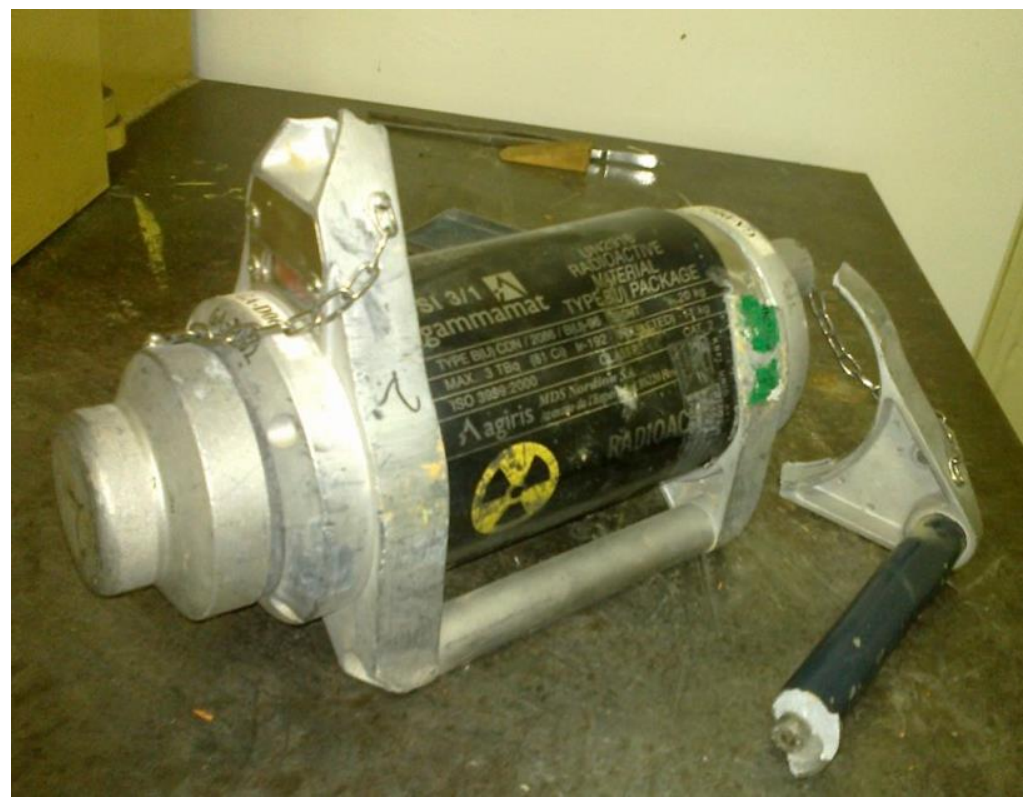

8. ábra A balesetben sérült Gammamat munkatartó [15]

$\mathrm{Az}$ esemény során a sugárforrás nem került ki az árnyékolt tartóból, így többlet sugárterhelést nem okozott sem a lakosság, sem pedig a dolgozók számára. Az alkalmazott sugárforrás 2. kategóriájú volt az atomenergia alkalmazása körében a fizikai védelemről és a kapcsolódó engedélyezési, jelentési és ellenőrzési rendszerről szóló 190/2011. (IX. 19.) Korm. rendelet 1. mellékletének 2. táblázata szerint, mivel az $\mathrm{R}$ értéke 13,75-nek adódott $\left(\mathrm{R}=\mathrm{A}_{\mathrm{i}} / \mathrm{D}_{\mathrm{i}}=1,1 \mathrm{TBq} / 8 \cdot 10^{-2} \mathrm{TBq}\right)$. [16][17] A mélységben tagolt védelmek nem sérültek, mivel a sugárforrás az árnyékolását nem vesztette el, illetve nem került ki a környezetbe. Mindezeket figyelembe véve az esemény INES besorolása nem érhette el a kötelezően NAÜ irányába bejelentendő szintet, azaz a legalább INES 2.

\section{ÖSSZEFOGLALÁS}

Az atomerőmüvekben bekövetkezett komolyabb balesetek elemzésével foglalkozó cikk sorozat bemutatja a windscale-i reaktorban, Three Mile Island atomerőmüben, a csernobili atomerőmüben, valamint a fukushimai atomerőmüben történt baleseteket és azok hatásait. [18] [19]

A bemutatott balesetek következményeinek súlyossága meghaladja az ipari radiográfiás munkatartó sérülésével és így a zárt sugárforrás kikerülésével járó balesetek következményeit, de a bemutatott hatások azt mutatják, hogy könnyen okozhat a kikerülő sugárforrás a determinisztikus hatások küszöb dózisánál magasabb értékeket. Ez föként akkor fordult, fordulhat elő, ha nem tudnak arról, hogy a munkatartón kívülre került a sugárforrás. A cikkben bemutattuk, hogy ezek az eszközök fel vannak készítve a kívülről érkező hatásoknak, melyeket különböző tesztekkel igazolnak.

Az elsőként odaérkező egységeknél jelent kockázatot az, hogy az elhárítást az életmentés miatt azonnal meg kell kezdeniük. Ennek kezelése érdekében került megalkotásra a hiányzó, a talált, valamint a lefoglalt nukleáris és más radioaktív anyagokkal kapcsolatos bejelentésekről és intézkedésekről, továbbá a nukleáris és más radioaktív anyagokkal kapcsolatos egyéb bejelentést követő intézkedésekről szóló 490/2015. (XII. 30.) Korm. rendelet. [20] A rendelet szerint, ha bárki által talált anyagról feltételezhetö, hogy az radioaktív anyag, illetve ilyen anyaggal szennyezett, akkor haladéktalanul értesíteni kell a hivatásos katasztrófavédelmi szerv területileg illetékes szervét. Az ország mind a 19 megyéjében és a fövárosban a katasztrófavédelemnél Katasztrófavédelmi Mobil Labor egységek állnak készenlétben a nap 24 
órájában, amelyek rendelkeznek vegyi, biológiai, nukleáris és radiológiai események felszámolásához szükséges monitoring eszközökkel. Ennek megfelelöen egy káresetnél helyszíni méréseket végeznek, szükség szerint megteszik az azonnali lakosságvédelmi intézkedéseket, valamint a talált anyagot lefoglalják és átadják a rendeletben meghatározott szervezetnek elszállítás céljából.

A cikkben bemutatott ceglédi baleset kapcsán is megállapítható, hogy a sugárforráshoz igen közel tartózkodva kaphatnak az ott lévő mentést végzők akkora sugárterhelést, ami determinisztikus hatást okozhatna. A mentést végzők, valamint a lakosság életének és testi épségének a védelme, biztonsága érdekében volt szükség az ilyen esetek kezelésére vonatkozóan a beavatkozással kapcsolatos feladatok jogszabályban történő rögzítésére.

\section{FELHASZNÁLT IRODALOM}

[1] AGMI Zrt. hivatalos honlapja: http://www.agmi.hu/radiografiai-vizsgalatok/ (A letöltés ideje: 2018. december 17.)

[2] International Atomic Energy Agency - Nuclear Data Section hivatalos honlapja: https://www-nds.iaea.org/relnsd/vcharthtml/VChartHTML.html (A letöltés ideje: 2018. december 17.)

[3] A The Welding Intstitute hivatalos oldala: https://www.twi-global.com/ (A letöltés ideje: 2018. december 17.)

[4] A QSA Global hivatalos oldala: https://qsa-global.com/wpcontent/uploads/2018/07/2016-Iridium-SourcesV2.pdf (A letöltés ideje: 2018. december 17.)

[5] A High Technology Sources Limited hivatalos honlapja: http://hightechsource.co.uk/sentinel-source-projectors/ (A letöltés ideje: 2018. június 07.)

[6] A GRIMAS Ipari Kereskedelmi Kft. hivatalos honlapja: http://www.grimas.hu/roncsolasmentes/izotop-tartok/standard-izotop-tartok/gammamattsi-iridium-izotop-tarto/ (A letöltés ideje: 2018. december 17.)

[7] D. Delacroix, J. P. Guerre, P. Leblanc, C. Hickman: Radionuclide and radiation protection data handbook 2002. Nuclear Technology Publishing (2002) https://www.nuc.berkeley.edu/sites/default/files/resources/safetyinformation/Radionuclide_Data_Handbook.pdf

[8] Unger, L.M.; Trubey, D.K.: Specific gamma-ray dose constants for nuclides important to dosimetry and radiological assessment. Oak Ridge National Lab., TN (USA) 2015 május

[9] A RadPro Calculator hivatalos honlapja: http://www.radprocalculator.com/Gamma.aspx (A letöltés ideje: 2018. június 07.)

[10] Ballay L., Elek R., Vida L., Turák O.: A kiterjesztett INES skála alkalmazása hazai radiológiai eseményekre. Sugárvédelem IV. évf. (2011) 1. szám., http://www.sugarvedelem.hu/sugarvedelem/docs/V4i1/Bal_V4_I1final.pdf

[11] Zelenák J., Csurgai J., Halász L., Solymosi J., Vincze Á.: A légi sugárfelderítés képességei alkalmazhatóságának vizsgálata elveszett vagy ellopott sugárforrások felkutatása, illetve szennyezett terepszakaszok felderítése során. Hadmérnök 4:(1) pp. 4662. (2009), http://hadmernok.hu/2009_1_zelenak.pdf 
[12] Bali T.: Helikopterek alkalmazásának lehetőségei és korlátai a kiképzés aspektusából. Hadtudományi szemle 4:(1), pp. 22-29. Budapest, 2011, http://archiv.uninke.hu/downloads/kutatas/folyoiratok/hadtudomanyi_szemle/szamok/2011/2011_1/201 1_1_hm_bali_tamas_22_29.pdf

[13] J Solymosi, E Baumler, A Sarkadi, Á Gujgiczer, I Pintér, Á Vincze: Wide range universal radiation measuring instrument. Academic and Applied Research in Military Science 1:(1) pp. 133-144. (2002) http://archiv.uninke.hu/downloads/aarms/docs/Volume1/Issue1/pdf/10soly.pdf

[14] Az index.hu hivatalos oldala:

https://index.hu/belfold/2012/12/11/nuklearis_anyagot_szallito_teherauto_utkozott_inte rcityvel/ (A letöltés ideje: 2018. december 17.)

[15] Kalászi P., Sebestyén Zs., Ballay L., Juhász L., Motoc A., Váradi Cs., Vida L., Salik Á., Sáfrány G.: Az Országos Sugáregészségügyi Készenléti Szolgálat bemutatása. In XXXVIII. sugárvédelmi továbbképző tanfolyam, Hajdúszoboszló, 2013.04.23., http://www.sugarvedelem.hu/sugarvedelem/docs/kulonsz/2013sv/pdf/az_orszagos_suga regeszsegugyi keszenleti szolgalat bemutatasa.pdf

[16] 190/2011. (IX. 19.) Korm. rendelet az atomenergia alkalmazása körében a fizikai védelemröl és a kapcsolódó engedélyezési, jelentési és ellenörzési rendszerröl

[17] 11/2010. (III. 4.) KHEM rendelet a radioaktív anyagok nyilvántartásának és ellenörzésének rendjéröl, valamint a kapcsolódó adatszolgáltatásról

[18] Dobor J.; Kossa Gy.; Pátzay Gy.: Atomerőmüvi balesetek és üzemzavarok tanulságai 1. Hadmérnök, 12:(1) pp. 58-71 (2017. március), http://www.hadmernok.hu/171_06_dobor.pdf

[19] Dobor J.; Kossa Gy.; Pátzay Gy.: Atomerőmüvi balesetek és üzemzavarok tanulságai 2. Hadmérnök, 12:(4) pp. 84-98 (2017. december), http://www.hadmernok.hu/174_09_dobor.pdf

[20] 490/2015. (XII. 30.) Korm. rendelet a hiányzó, a talált, valamint a lefoglalt nukleáris és más radioaktív anyagokkal kapcsolatos bejelentésekröl és intézkedésekröl, továbbá a nukleáris és más radioaktív anyagokkal kapcsolatos egyéb bejelentést követö intézkedésekröl 